\title{
An overview of the treatment of cutaneous leishmaniasis
}

\author{
Talissa F. Garza-Tovar ${ }^{1} \quad$ Marco I. Sacriste-Hernández ${ }^{1} \quad$ Eder R. Juárez-Durán ${ }^{2}$ Roberto Arenas (iD ${ }^{2}$ \\ ${ }^{1}$ Dermatology Department, Hospital of Specialties 25 IMSS, Monterrey, Nuevo León \\ ${ }^{2}$ Mycology Section, “Dr. Manuel Gea Gonzalez” General Hospital, Mexico City, Mexico
}

\begin{abstract}
Leishmaniasis is a neglected tropical disease caused by species of Leishmania, with a broad spectrum of clinical manifestations, such as cutaneous, visceral, and mucocutaneous presentations. Many drugs are used for its treatment, and a current effective one is a pentavalent antimonial, especially in developing countries. In this review, we discuss recent proposed therapies as well as their side effects.
\end{abstract}

\section{Keywords}

Leishmaniasis, Treatment, Antimonials

\section{Peer Review}

The peer reviewers who approve this article are:

1. Byron Arana, Drugs for Neglected Diseases Initiative (DNDi), Geneva, Switzerland

Competing interests: No competing interests were disclosed.

2. Roberto Nicolete, Laboratório de Biotecnologia, Fundação Oswaldo Cruz (Fiocruz Ceará), Eusébio, CE, Brazil Competing interests: No competing interests were disclosed.

*Corresponding author: Roberto Arenas (rarenas98@hotmail.com)

Competing interests: The authors declare that they have no competing interests.

Grant information: The authors declared that no grants were involved in supporting this work.

Copyright: C 2020 Arenas R et al. This is an open access article distributed under the terms of the Creative Commons Attribution License, which permits unrestricted use, distribution, and reproduction in any medium, provided the original work is properly cited.

How to cite this article: Garza-Tovar TF, Sacriste-Hernández MI, Juárez-Durán ER and Arenas R. An overview of the treatment of cutaneous leishmaniasis. Faculty Reviews 2020 9:(28) https://doi.org/10.12703/r/9-28

Published: 22 Dec 2020, Faculty Reviews 9:(28) https://doi.org/10.12703/r/9-28 


\section{Introduction}

Leishmaniasis is a neglected tropical disease caused by species of Leishmania and transmitted to humans by the bite of a sandfly, mainly Phlebotomus and Lutzomyia (Old World and New World, respectively) ${ }^{1}$. It is a major public health problem with a broad spectrum of clinical manifestations and epidemiological diversity with different degrees of severity that depend on the involved intracellular parasite and the immune response of the host. It has a wide distribution and is endemic in circumscribed areas in Northeastern Africa, Southern Europe, the Middle East, Mexico, and Central and South America ${ }^{1}$. In its treatment, many drugs are used, but around $50 \%$ of satisfactory clinical and microbiological results for almost all clinical forms are achieved with a current pentavalent antimonial. This review evaluates recently proposed treatments and their side effects.

\section{Local and intralesional therapy}

Local therapies have been recommended by the World Health Organization (WHO), the Pan American Health Organization (PAHO), and other experts as an alternative to systemic drugs in patients with at least four lesions smaller than $4 \mathrm{~cm}$ in diameter, especially when the face or joints are not affected. Usually, they are easy to use and have a lower risk, toxicity, and cost compared to traditional therapies. Local treatment includes thermotherapy, cryotherapy, and topical and intralesional drugs. The last approach is effective and safe in localized forms ${ }^{2-4}$.

\section{Intralesional antimonials}

The use of intralesional therapy with antimonials was introduced with the aim of reducing adverse effects compared to their systemic administration. It was recommended as an acceptable therapeutic alternative for New World leishmaniasis by the WHO Expert Committee on Leishmaniasis in 2010 and by the PAHO Expert Committee on Leishmaniasis in $2013^{5,6}$. In a systematic review of the efficacy of pentavalent antimoniate intralesional infiltration for cutaneous leishmaniasis (CL), the authors found an efficacy rate in the Old World of $75 \%$ with intralesional pentavalent antimony (SbV) (higher when it was combined with cryotherapy), $83 \%$ with sodium stibogluconate (SSG), and 68\% with meglumine antimoniate (MA). In the New World, the efficacy rate was $77 \%$ with intralesional infiltration $\mathrm{SbV}, 61 \%$ with $\mathrm{SSG}$, and $82 \%$ with $\mathrm{MA}^{7}$. We must consider that this therapy requires the infiltration of each lesion so is not for all cases of CL. The recommended dose is $1-5 \mathrm{~mL}$ (applied in five sites per lesion) every 3-7 days until healing; the only adverse events reported were local irritation, pain, edema, erythema, and pruritus ${ }^{3,8}$.

\section{Thermotherapy/heat therapy}

Thermotherapy is a local treatment based on studies that have demonstrated in vitro growth inhibition of Leishmania in macrophages at temperatures $>39^{\circ} \mathrm{C}$; moreover, heat and the immediate collagen contraction stimulates the destruction of parasites $^{2}$. Thermotherapy can be administered with infrared light, laser, or direct electrical stimulation. Radiofrequency has advantages over other local treatments for Old and New World Leishmaniasis ${ }^{8,9}$. One is that radiofrequency waves penetrate uniformly to a depth of $4 \mathrm{~mm}$, so the amastigote can be heated with high temperatures without damaging the surrounding skin, and waves can be applied locally with portable, battery-operated, and localized current fields (ThermoMed). This device is safe compared with other traditional treatments and easy to use in rural areas without electricity; however, the thermotherapy machine is expensive. Heat therapy is recommended for lesions caused by any species of Leishmania, and the main side effects are pain, itching, burning sensation, and even second-degree burns ${ }^{2,9,10}$. It can be used with systemic treatments and is an alternative approach in pregnant women with localized leishmaniasis or patients who have contraindications to systemic therapy ${ }^{3}$. It has been reported that a single application of radiofrequency thermotherapy at $50^{\circ} \mathrm{C}$ for 30 seconds is an effective and safe treatment, with cure rates of 87 to $98 \%$. The discrepancy between the cure rates may be due to other factors like host immunological response, nutritional status, and different Leishmania spp., ${ }^{911,12}$. It is important to consider that this therapy generates a local thermal dose, so it might not be possible to cure distant lesions, such as in patients with lymph node and mucosal involvement, especially in regions with a high prevalence of mucosal leishmaniasis ${ }^{9}, 13$.

\section{Cryotherapy}

Cryotherapy is a physical therapy that uses subzero temperatures and is effective because all Leishmania species are thermosensitive. Liquid nitrogen at $-196^{\circ} \mathrm{C}$ is applied directly to the lesion, reaching a lethal temperature ${ }^{14}$. It has to be applied to the skin for 15-20 seconds, extending 1-2 mm outside of the lesion, and has to be repeated three times per session every 3 weeks. The result of treatment in local tissues is direct damage, with the destruction of amastigotes, which induces an immune response to the liberation of cellular antigenic substances ${ }^{3,15-17}$. Tolerance to the application of cryotherapy is adequate, and it is a low-cost treatment with few side effects, such as erythema, edema, and residual hypopigmentation or hyperpigmentation ${ }^{2,18}$. However, despite the advantages of this local therapy, there are large discrepancies among the findings of some controlled trials: some report success in more than $95 \%$ of cases, while in some others the percentage of successful cases is $27 \%^{16}$. A systematic review of the efficacy of pentavalent antimoniate intralesional infiltration therapy for CL found that the cure rate with antimony intralesional infiltration combined with cryotherapy was higher than antimony intralesional infiltration alone (odds ratio [OR] 3.14, $P=0.013)^{7}$. The above is correlated with several studies that have shown that CL responds better to the combination of cryotherapy with antimony intralesional infiltration than each technique alone ${ }^{8,15,19}$.

\section{Lasers}

$\mathrm{CO}_{2}$ laser. $\mathrm{CO}_{2}$ laser therapy for $\mathrm{CL}$ causes a specific thermolysis effect on infected tissue and has fewer side effects on normal $\operatorname{skin}^{2,8,20}$. In Iran, researchers compared the efficacy of $\mathrm{CO}_{2}$ laser with a combination of cryotherapy and intralesional MA; they showed that the first approach was more effective, 
with a complete response in up to $93 \%$ of patients. They used a $\mathrm{CO}_{2}$ laser system with a maximum power of $30 \mathrm{~W}$, pulse duration of $0.01-1$ second, and a mode of continuous wave ${ }^{20}$. In Israel $^{21}, 10$ pediatric patients with a diagnosis of CL were treated with fractional $\mathrm{CO}_{2}$ laser (spot size $120 \mathrm{~mm}$, fluence 15-100 mJ, and density 3-5\%) followed by immediate topical application of SSG; $90 \%$ achieved clinical cure with good final cosmetics. The $\mathrm{CO}_{2}$ laser is safe and effective with few sessions and is associated with mild side effects, such as hyperpigmentation and hypertrophic scars ${ }^{2,21}$.

Argon laser. A review of the literature on the application of laser for the treatment of CL found one report of argon laser as treatment ${ }^{22}$. Rakaheev et al. reported complete clinical cure of a patient who had failed antibiotic treatment; they treated the patient with six sessions of argon laser therapy with intervals of 4-5 days ${ }^{23}$. As this is the only study reporting on this treatment modality, more studies are needed.

Erbium glass laser. Mashayekhi et al. reported the use of erbium glass laser for the treatment of $\mathrm{CL}^{24}$. The study was conducted in Iran, and the authors treated 14 patients with 20 lesions of Old World CL (OWCL) using erbium glass laser $1540 \mathrm{~nm}$ weekly $(10 \mathrm{~mm}$ spot size handpiece with $10 \mathrm{~ms}$ pulse duration and $50-70 \mathrm{~mJ} / \mathrm{cm}^{2}$ fluence in four passes). Only nine patients with 12 lesions ended the protocol, and $91.66 \%$ of the lesions improved completely at 6 weeks of treatment. The side effects reported were pain during the procedure, erythema, and edema. The authors concluded that it may be a promising method for the treatment of $\mathrm{CL}^{24}$.

Neodymium-doped yttrium aluminum garnet laser. The use of neodymium-doped yttrium aluminum garnet (Nd:YAG) laser as a treatment for CL was reported in one study in which the authors compared Nd:YAG laser therapy with intralesional $\mathrm{MA}^{25}$. They treated the CL lesions of 16 patients simultaneously, treating one lesion with $1,500 \mathrm{mg} / 5 \mu \mathrm{l}$ of MA weekly (until complete recovery of the lesion) and another lesion with Nd-YAG laser $\left(200 \mathrm{~mJ} / \mathrm{cm}^{2}\right.$, pulse duration $20 \mathrm{~ms}$, spot size $3 \mathrm{~mm}$ indexes). The sessions with Nd-YAG laser were repeated at intervals of 2 weeks until complete cure with a negative direct smear of the lesion. The mean number of sessions with Nd-YAG was $2.56 \pm 0.89$ and for MA injection was $7.31 \pm$ $4.01(P<0.001)$. Scars were observed in 10 patients of the Glucantime-based treatment group and only three patients of the laser group. The laser scars were smaller but were more often associated with post-inflammatory hyperpigmentation. The authors concluded that laser therapy might be an effective alternative treatment for $\mathrm{CL}$ with fewer complications ${ }^{25}$.

Pulsed dye laser. The mechanism of action of pulse dye laser (PDL) on CL is not completely understood; however, it is believed that cutaneous lesions have an important vascular component owing to the identification of dermoscopic vascular patterns in $100 \%$ of leishmania lesions reported in a study, a fact that could explain the efficacy of PDL. Other possible mechanisms of action are the heat ablation of the Leishmania bodies, following the basis of thermotherapy, and the cutaneous immunological activation induced by the $\mathrm{PDL}^{26}$. Slaoui et al. used PDL $595 \mathrm{~nm}$ to treat the erythematous papules and nodules of leishmania in three patients using the following parameters: spot size $10 \mathrm{~mm}$ and energy $8 \mathrm{~J} / \mathrm{cm}^{2}$. They reported improvement in texture and scar size ${ }^{26}$. Elsaie and Ibrahim treated 25 cutaneous lesions of 12 patients with a single pass over the whole lesion using a fluence of $7 \mathrm{~J} / \mathrm{cm}^{2}, 10 \mathrm{~mm}$ spot size, and a pulse duration of $0.45 \mathrm{~ms}$; they reported full cure in 13 of the 25 lesions after three sessions, while 12 of the remaining 25 lesions required four sessions toward complete recovery. They reported that PDL is an effective and safe treatment ${ }^{27}$.

\section{Topical paromomycin}

Paromomycin (formerly aminosidine) is an antibacterial aminoglycoside available in parenteral and $15 \%$ topical formulations that has efficacy against Leishmania ${ }^{28,29}$. It has been used in topical formulations; one of these is the combination of $15 \%$ paromomycin with $12 \%$ methylbenzethonium chloride, which, when applied for 20 days, showed a $77 \%$ efficacy compared to $27 \%$ for placebo, but severe irritancy and intolerance has been associated with methylbenzethonium ${ }^{29,30}$. A study conducted in Panama similar to a trial conducted in Tunisia used a new formulation (paromomycin-gentamicin cream), which demonstrated a cure rate of $79 \%$ against New World Leishmania species, with mild local adverse events ${ }^{29,31}$. It is important to emphasize that the results from the Tunisia and Panama studies were obtained using a different formulation than the one used in previous studies, where either methylbenzethonium chloride or urea was used as a vehicle and use had to stop owing to side effects. This problem about safety has not been observed with the new formulation used in Panama and Tunisia.

\section{Systemic therapy}

Antimonials

Meglumine antimoniate and sodium stibogluconate. $\mathrm{SbV}$ compounds are highly effective and the first-line treatment for most forms of leishmaniasis; these are SSG (Pentostam ${ }^{\circledR}$ ) and MA (Glucantime $\left.{ }^{\circledR}\right)^{18,28}$. MA is administered intramuscularly or intralesionally (Figure 1 and Figure 2) and SSG is administered intravenously or intralesionally at the recommended dose of $20 \mathrm{mg} / \mathrm{kg} / \mathrm{day}$ for 20 days $^{28}$. They have many adverse effects, the most frequent of which are cardiotoxicity, rise in liver function test, urea, and creatinine, anorexia, nausea, vomiting, myalgia, and arthralgia, whereas when applied intralesionally they may cause local irritation, pain, edema, erythema, or pruritus ${ }^{1,8}$. Both intralesional and systemic antimonials are recommended by the WHO and PAHO for CL treatment ${ }^{32,33}$. Castelano et al. in a systematic review reported similar efficacy rates of intralesional SbV use in Old and New World CL. They also found that treatments with a duration of more than 14 days had higher cure rates ${ }^{7}$. A systemic antimonial is indicated for mucocutaneous forms, with a cure rate of almost $75 \%$, which depends on the causal species and the severity of the disease. The recommended dosage is $20 \mathrm{mg} / \mathrm{kg} /$ day for $28-30$ days $^{1,8,28}$. 


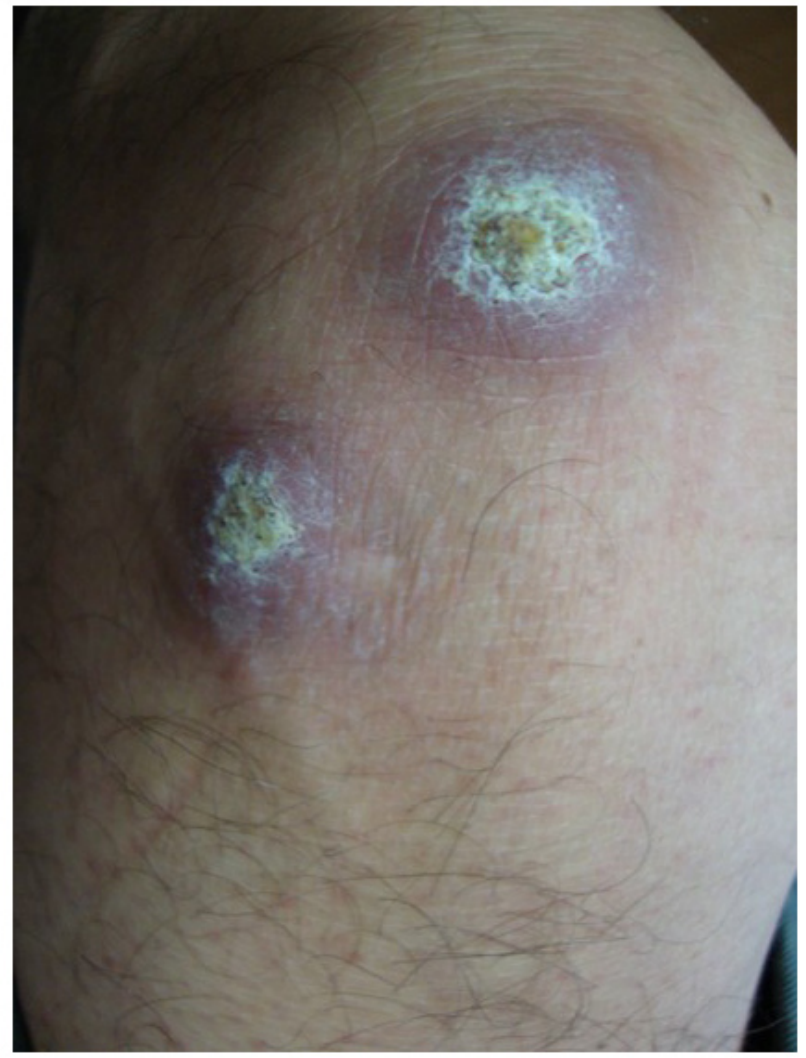

Figure 1. Cutaneous leishmaniasis in a Mexican patient.

\section{Antifungals}

The azole molecules (imidazoles and triazoles) block the ergosterol synthesis of Leishmania parasites. Ketoconazole, itraconazole, and fluconazole have been used for CL in many studies with variable cure rates ${ }^{8,34}$. Important advantages of azoles are oral administration and fewer side effects ${ }^{28}$. A systematic review and meta-analysis which included studies involving outcomes showed a pooled azole final efficacy rate of $64 \%$ for the treatment of CL, finding a higher healing rate in Leishmania mexicana (89\%), Leishmania infantum (88\%), and Leishmania donovani $(80 \%)$ and lower cure rates for Leishmania major (53\%), Leishmania braziliensis (49\%), and Leishmania tropica $(15 \%)^{35}$. A randomized controlled trial in India compared oral itraconazole $200 \mathrm{mg} /$ day for 6 weeks versus no treatment and showed complete cure in $66.7 \%$ of the itraconazole group and none of the placebo group ${ }^{18}$. In Italy, pediatric patients with OWCL were treated with fluconazole at a dose of $6 \mathrm{mg} / \mathrm{kg}$ daily for 6 weeks and exhibited complete cure ${ }^{36}$. Long-term treatment with azoles have toxicity risks, such as hepatotoxicity and QTc prolongations, which is why the recommended dosage of fluconazole is $200 \mathrm{mg}$ or $400 \mathrm{mg}$ daily for 6 weeks, ketoconazole $600 \mathrm{mg}$ daily for 28 days, and itraconazole $100 \mathrm{mg}$ twice daily for $42-56$ days $^{3}$.

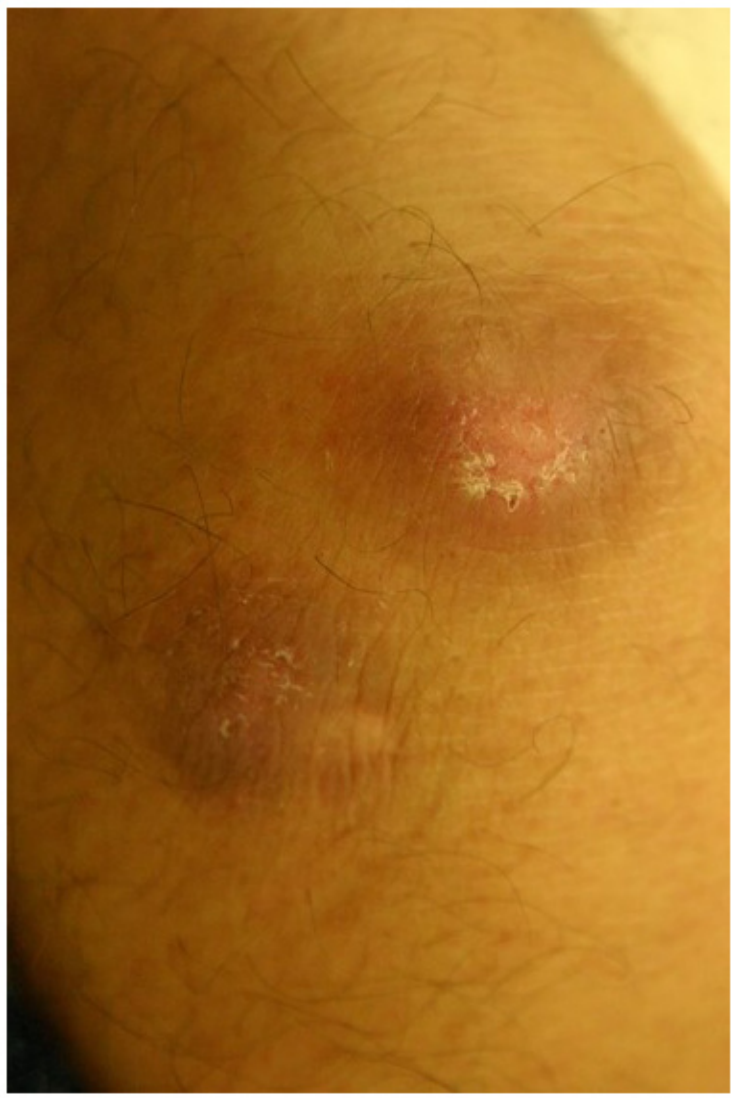

Figure 2. After four doses of intralesional meglumine antimoniate.

Amphotericin B. Amphotericin B (AmB) is a macrolide polyene antibiotic with potent antifungal and anti-leishmanial activity that targets ergosterol, the principal membrane component of Leishmania spp. ${ }^{37,38}$. It is considered a second-line treatment for CL. There are four formulations of AmB: one is amphotericin B deoxycholate, and the rest are lipid formulations of the drug, liposomal amphotericin, cholesterol dispersion amphotericin, and lipid complex amphotericin ${ }^{2,8,37}$. The three lipid formulations were made to minimize adverse events such as nephrotoxicity reported with amphotericin B deoxycholate; however, the only drug of this type approved by the US Food and Drug Administration (FDA) is liposomal amphotericin B $(\mathrm{L}-\mathrm{AmB})^{8}$. L-AmB has an efficacy of $95-100 \%$ in visceral leishmaniasis ${ }^{39}$. However, there are a few studies of CL treatment with L-AmB, and they show big differences in the reported cure rates and the total doses used $^{8}$. A review of L-AmB treatment of OWCL reported that L-AmB had an $85 \%$ cure rate in immunocompetent patients with OWCL but also found a high variety of total treatment dosages, which limits the reported data, so the authors concluded that there is a need for randomized controlled trials comparing systemic treatments ${ }^{39}$. 
Miltefosine. Miltefosine is an alkyl phospholipid and is the only oral drug for the treatment of leishmaniasis that is approved by the FDA. It was approved in 2014 as a treatment for CL caused by L. braziliensis, Leishmania panamensis, and Leishmania guyanensis. The efficacy results from clinical trials, most of them for New World CL, have high variability between countries and the different Leishmania species. The reported cure rates range from $50 \%$ (L. braziliensis in Colombia) to $88 \%$ (L. major in Afghanistan $)^{8,40,41}$. The FDA regimen is $2.5 \mathrm{mg} / \mathrm{kg} /$ day for 28 days, with a maximum dose of $150 \mathrm{mg} /$ day owing to poor gastrointestinal tolerability. The main disadvantage of miltefosine treatment is the high incidence of gastrointestinal adverse events, the most common of which are vomiting and diarrhea (62\% of patients). Hepatic toxicity and nephrotoxicity can occur in $10-15 \%$ of patients. It is also teratogenic; thus, it requires women of childbearing age to avoid pregnancy during treatment and for 3 months after finishing treatment. Moreover, it has a long half-life, which makes it vulnerable to the development of drug resistance ${ }^{8,40-42}$.

Pentamidine isethionate. Pentamidine is an antiprotozoal and antifungal agent of the group of aromatic diamidines that can be administered intravenously or intramuscularly in leishmaniasis ${ }^{18}$. It is exclusively used for L. guyanensis. The recommended dose is $4 \mathrm{mg} / \mathrm{kg} /$ day on alternate days (maximum dose of $240 \mathrm{mg} / \mathrm{day})^{3,8}$. Christen et al. reported a higher efficacy of the intravenous administration of pentamidine isethionate $(85.3 \%)$ versus intramuscular administration $(51.3 \%)$ in L. guyanensis $\mathrm{CL}^{43}$. However, it is generally used as a second-line treatment owing to nephrotoxicity, hepatotoxicity, pancreatitis leading to insulin-dependent diabetes, hypertension, hypoglycemia, QT prolongation, hyperkalemia, and vertigo ${ }^{1,3,8}$.

\section{Antidepressants}

Sertraline. Sertraline is an interesting example of repurposing drugs for treatment. It is a selective serotonin reuptake inhibitor (SRRI) prescribed for depression and anxiety. Lima et al. assessed the detrimental effects of sertraline on $L$. infantum and how it inhibited the proliferation of promastigotes with $\mathrm{IC}_{50}$ and $\mathrm{IC}_{90}$ values of $2.0 \pm 0.7 \mu \mathrm{M}$ and $8.4 \pm 1.8 \mu \mathrm{M}$, respectively, and intracellular amastigotes with $\mathrm{IC}_{50}$ and $\mathrm{IC}_{90}$ values of $3.9 \pm 0.3 \mu \mathrm{M}$ and $7.9 \pm 0.1 \mu \mathrm{M}$, respectively. Sertraline had no toxic effects on murine macrophages ${ }^{44}$.

Romanella et al. assessed the efficacy of sertraline entrapped in phosphatidylserine liposomes (LP-SERT) in a murine model of visceral leishmaniasis. This treatment was able to reduce the liver parasite burden by $72 \%$ at $0.3 \mathrm{mg} / \mathrm{kg}(P<0.05)$ and by $89 \%$ at $1 \mathrm{mg} / \mathrm{kg}(P<0.05)$ when compared with the placebo group (only liposomes), who experienced no effect ${ }^{45}$.

Clomipramine is a tricyclic antidepressant used for some psychiatric disorders. Da Silva Rodrigues et al. assessed its activity in Leishmania amazonensis and found that it was a selective inhibitor of the intracellular and extracellular forms. It inhibited macrophage cellular growth by 50\%. It appears to induce morphological alterations, oxidative stress, mitochondrial impairment, and autophagy, so further studies are needed in animal models ${ }^{46}$.

\section{Amiodarone}

Amiodarone is a potent antiarrhythmic whose anti-leishmanial activity was reported recently in different studies ${ }^{47,48}$. The mechanisms of action as an anti-leishmanial are inhibition of sterol biosynthesis, destabilization of $\mathrm{Ca}^{2+}$ homeostasis, the collapse of mitochondrial membrane potential, and production of reactive oxygen species ${ }^{49,50}$. In a study from Iran, researchers studied the effectiveness of amiodarone against $L$. major and reported that it reduced the lesion surface area but didn't result in complete cure, suggesting that combination therapy with amiodarone may yield better results ${ }^{49}$.

\section{Immunomodulators}

Cyclosporin A and dihydrocyclosporin A. Cyclosporin A (CsA) exhibits its immunosuppressive action by inhibiting the production of calcineurin through binding to cyclophilin A (CyPA). $L$. donovani expresses a variant of CyPA (LdCyPA) that is different to those of humans and has a role in the survival of parasites in the tissues ${ }^{51}$. Dihydrocyclosporin A (DHCsA-d) (a co-metabolite of CsA) has minimum immunosuppressive activity and also inhibits L. donovani in vivo and in vitro. Zheng et al. evaluated the efficacy of both drugs against promastigotes and amastigotes of $L$. donovani versus SSG as a positive control. Intracellular amastigotes decreased compared to the untreated group after the administration of DHCsA-d or SSG ${ }^{51}$. Also, the intracellular amastigotes increased after the administration of CsA, and it appears that only the last was found to promote intracellular amastigotes ${ }^{51}$.

Imiquimod. Imiquimod can be used in combination with standard therapy with cure rates above $90 \%$. It appears to interact with the Toll-like receptors and induces activation of the $\mathrm{NF}-\kappa \mathrm{B}$ pathway, thus inhibiting amastigote replication. It also induces the production of nitric oxide (NO) by macrophages, which could lead to Leishmania destruction ${ }^{52}$.

Verastegui-Miranda et al. led a randomized double-blind trial comparing treatment outcome with pentamidine and the outcome with pentamidine intralesional infiltration + imiquimod (three times/week for 20 days). They found a cure rate of $75 \%$ in the pentamidine + imiquimod group versus $58 \%$ in the pentamidine alone group ${ }^{53}$. The same group also led a randomized double-blind study in 2005 for treatment with imiquimod versus Glucantime. They found that the group treated with imiquimod reached cure faster $(50 \%$ achieved cure at 1 month versus $15 \%$ in the placebo group). As for the adverse events, erythema was more frequent in the imiquimod group ${ }^{54}$.

Arevalo et al. used imiquimod as monotherapy for Leishmania peruviana and showed a transient effect with minimal reduction of the lesion size in the first few days but without cure ${ }^{55}$. Mejravaran et al. studied the effects of imiquimod liposomes containing Leishmania antigens in a murine model. The smallest lesions at the end of the study were observed in mice who 
had received liposomes + imiquimod compared to other mice $(P<0.05)^{56}$.

\begin{abstract}
Alternative treatments
Plant-derived treatments

Chalcones (benzylideneacetophenones or 1,3-diaryl-2-propen-1ones) are plant metabolites and precursors of isoflavonoids and flavonoids. At least 312 compounds with the chalcone skeleton have anti-leishmanial activity, 34 derived from plants of the Fabaceae and Piperaceae. All of them, natural and synthetic or semisynthetic, showed varying degrees of this activity ${ }^{57}$. An extract of Piper aduncum (Piperaceae) led to the isolation of 2',6'-dihydroxy-4'-methoxychalcone (DMC2), which inhibited promastigotes of $L$. amazonensis but had less of an effect on amastigotes. There were no toxic effects on macrophages ${ }^{57}$.
\end{abstract}

Arrabidaea brachypoda. Three flavonoids from A. brachypoda have shown anti-Trypanosoma cruzi activity. Rocha et al. investigated the anti-leishmanial activity of three dimeric flavonoids in vitro and selected the most active (Brachydyn2) for in vivo testing in a model of $\mathrm{CL}$ in which treated amastigotes showed cell lesion induced by Brachydyn 2, which led to death of the parasite ${ }^{58}$.

Styrylpyrone. Extracts from species of the Lauraceae family of the Amazon have shown in vitro anti-leishmanial activity. Styrylpyrone 4-methoxy-6-(11,12-methylenedioxy-trans-styryl)2-pyrone (SP) derived from Aniba panurensis was evaluated in vitro against $L$. amazonensis promastigotes, which were treated with different concentrations of SP, affecting the growth of the parasite ${ }^{59}$. The mechanism of action involves impairment in cell division and, in an attempt to maintain homeostasis, the parasite will initiate an autophagic process, leading to cell collapse and death ${ }^{59}$.

Piper marginatum. Essential oils from Piper marginatum showed phenolic compounds, terpenoids, and 3,4-methylenedioxy propiophenone as major compounds. These fractions have antipromastigote and antiamastigote properties against L. amazonensis in vitro. They showed low toxicity for macrophages and had the best selectivity index versus pentamidine (reference drug) ${ }^{60}$.

Origanum onites. The essential oil of Origanum species has shown antimicrobial properties, a few of them evaluated as antiprotozoal. Tasdemir et al. assessed the antiprotozoal activity of Origanum onites against some protozoa ${ }^{61}$. The main components of the oil were carvacrol $(70.6 \%)$, linalool $(9.7 \%)$, $p$-cymene (7\%), $\gamma$-terpinene $(2.1 \%)$, and thymol (1.8\%). It had in vitro activity against Trypanosoma brucei rhodesiense and moderate anti-leishmanial and anti-plasmodial effects. It did not show toxicity to mammalian cells. Some of these compounds were assessed individually with a decrease in their activity, suggesting that they have an additive action ${ }^{61}$.

Urtica dioica. Badirzadeh et al. studied the anti-parasitic effects of Urtica dioica aqueous extract in CL caused by $L$. major in vivo (mouse model) and in vitro. The results demonstrated that the optimal concentration for reducing amastigote and promastigote growth was 3,500 and $6,000 \mu \mathrm{g} / \mathrm{mL}$, respectively, killing both forms of the parasite. This study proves that $U$. dioica has potent action against Leishmania promastigotes and amastigotes. The possible mechanism of action is via modulation of the immune response. It did not show toxicity in macrophages ${ }^{62}$.

\section{Animal toxin-derived treatments}

Snake-derived venoms. Snake venoms are a complex mixture of peptides which have different pharmacological activities ${ }^{63}$. Venoms from Bothrops moojeni can inhibit the in vitro growth of Leishmania spp. because of L-amino acid oxidase ${ }^{63}$. Crotalus durissus terrificus (South American rattlesnake) has a variety of peptides in its venom: gyroxin, crotamine, convulxin, crotoxin, and others ${ }^{63}$. Crotoxin is the major toxic compound of this venom, and it has phospholipase A2 (PA2). PA2 from other snakes has action against promastigotes of Leishmania spp. ${ }^{63}$. Barros et al. showed that the PA2 isolated from $C$. $d$. terrificus inhibits the proliferation of $L$. infantum chagasi promastigotes at $50-200 \mu \mathrm{g} / \mathrm{mL}$ and that it was dose dependent. It appears that the interaction between PA2 and the lipid bilayer causes a rupture in the membrane, and this acts as an inhibitor of promastigote proliferation. It also induces the production of $\mathrm{NO}$ by macrophages (some Leishmania species can inhibit its production, escaping this mechanism of destruction), which can help the macrophages to suppress the infection in early stages $^{63}$.

Macedo et al. encapsulated the toxin of $C$. $d$. terrificus in a polymeric microparticle system and tested its activity in mice. They found that macrophages could better internalize the microparticle system versus toxin alone but both of them could promote the production of TNF- $\alpha$, which has an important intracellular role in inducing the production of $\mathrm{NO}$ and peroxide ions. The group with the microparticle system was able to decrease the number of amastigotes $(50.8 \%)$ versus the group without the toxin $(14.9 \%)^{64}$.

\section{Vaccines and immunotherapy}

It is possible to recover from primary infection caused by L. major and L. braziliensis, and the latter is associated with long-term protection against reinfection, indicating that a vaccine can be developed against CL. The interaction between the parasite and dendritic cells is crucial to develop CD4 and CD8 lymphocyte activation. This interaction leads to a release of IFN- $\gamma$ that induces the production of NO by macrophages. The vaccine is formed by two compounds: the antigen, to generate a specific immune response, and an adjuvant, which initiates and directs the immune response.

Five first-generation vaccines have been approved against Leishmania, two of them for administration to humans, and these vaccines use the whole parasite in either live or attenuated form (Brazil used it as immunotherapy for CL using killed L. amazonensis parasites and Uzbekistan used live attenuated 
parasites of $L$. major). There is also the risk of inducing the disease while using whole living parasites or introducing new species in non-endemic areas ${ }^{65}$.

Three vaccines of second generation (using recombinant antigens and specified adjuvants) have been developed for the immunization of dogs (Brazil). These three vaccines have proven to be effective in the short term, but the long-term efficacy remains unknown, so further studies are needed to know if it can reduce the spread of this disease. If used for immunotherapy, they need to be used in combination with traditional treatment. It would also need to be given in multiple injections to induce a satisfactory immune response ${ }^{65}$.

GP63 metalloproteinase is a protein on the surface of Leishmania that mediates protection against $L$. mexicana and $L$. major on mice but only partial protection in monkeys ${ }^{65}$.

Third-generation vaccines use specific pathogen RNA or DNA or a carrier that contains some gene components of the parasite to induce an immune response; it has been shown that the ones that use DNA are better at inducing the immune response than those using RNA, but they only showed acceptable results in mice because it is needed at a higher dose of DNA in larger animals and humans to induce the same immune response ${ }^{65}$.

LACK is the most-studied DNA vaccine against Leishmania; its use combined with IL-12 increased protection compared with LACK alone ${ }^{65}$.

There are no approved vaccines for human CL, but those that have advanced to some clinical trials (two vaccines, killed L. amazonensis, first generation) had inconsistent results between placebo and vaccine groups, so further studies are needed. There is a polyprotein-containing subunit vaccine (LEISHF1+MPL-SE) that appears to be safe, and it generates an antigen-specific Th1 lymphocyte response ${ }^{65}$. The most-evolved vaccines are based on recombinant molecules (LEISHF1, LEISHF2, and LEISHF3 have already entered human clinical trials, second-generation vaccines). LEISHF1 could efficiently treat $\mathrm{CL}$ and mucosal leishmaniasis, but it can also induce immunity in healthy individuals. LEISHF2 entered phase II trials, which are assessing its safety and therapeutic effect on CL patients versus chemotherapy alone ${ }^{66}$. The existence of veterinary vaccines and the development of clinical trials related to human disease are an indication that it is possible to develop a human vaccine. However, it is a difficult task, and this relies on the interaction between the host and parasite, which is complex ${ }^{66}$.

Immunotherapy had success in patients with mucocutaneous and diffuse CL. Moafi et al. treated promastigotes of L. braziliensis killed by pasteurization associated with viable Bacillus Calmette-Guérin (BCG), offering a safe option in disseminated $\mathrm{CL}$ which did not respond to conventional treatment ${ }^{67}$.

There is a third-generation vaccine employing adenovirus (ChAd63) that can induce a $\mathrm{CD}^{+}$response against Leishmania antigens and promotes the secretion of IFN- $\gamma$ by dendritic cells, which can lead to the prevention and treatment of Leishmania infection; it is still in phase II of a non-controlled randomized trial. It was focused as a single-dose therapeutic agent, and a single dose was safe and induced an adequate $\mathrm{CD}^{+}$ response $^{68}$.

\section{Conclusions}

Leishmaniasis remains a major public health problem with a broad spectrum of clinical manifestations related to the immune response of the host. New drugs are proposed for treatment, but results are still unsatisfactory. Currently, pentavalent antimonials are effective and available, but research must be a cornerstone in the proposal of novel therapies.
1. Torres-Guerrero E, Quintanilla-Cedillo MR, Ruiz-Esmenjaud J, et al:: Leishmaniasis: a review [version 1; peer review: 2 approved]. F1000Res. 2017; 6: 750 .

PubMed Abstract | Publisher Full Text | Free Full Text

2. Wolf Nassif $P$, de Mello TFP, Navasconi TR, et al:: Safety and efficacy of current alternatives in the topical treatment of cutaneous leishmaniasis: a systematic review. Parasitology. 2017; 144(8): 995-1004. PubMed Abstract | Publisher Full Text

3. Aronson NE, Joya CA: Cutaneous Leishmaniasis: Updates in Diagnosis and Management. Infect Dis Clin North Am. 2019; 33(1): 101-17. PubMed Abstract | Publisher Full Text

4. Uribe-Restrepo AF, Prieto MD, Cossio A, et al.: Eligibility for Local Therapies in Adolescents and Adults with Cutaneous Leishmaniasis from Southwestern Colombia: A Cross-Sectional Study. Am J Trop Med Hyg. 2019; 100(2): 306-10. PubMed Abstract | Publisher Full Text | Free Full Text

5. Ramalho DB, da Silva RE, de Senna MCR, et al:: Meglumine antimoniate intralesional infiltration for localised cutaneous leishmaniasis: a single arm, open label, phase II clinical trial. Mem Inst Oswaldo Cruz. 2018; 113(9): e180200. PubMed Abstract | Publisher Full Text | Free Full Text

6. de Aguiar MG, Gonçalves JE, Souza Md'A, et al.: Plasma antimony determination during cutaneous leishmaniasis treatment with intralesional infiltration of meglumine antimoniate. Trop Med Int Health. 2018; 23(10): 1110-7. PubMed Abstract | Publisher Full Text

7. Brito NC, Rabello A, Cota GF: Efficacy of pentavalent antimoniate intralesiona infiltration therapy for cutaneous leishmaniasis: A systematic review. PLOS One. 2017; 12(9): e0184777. PubMed Abstract | Publisher Full Text | Free Full Text

8. Chakravarty J, Sundar S: Current and emerging medications for the treatment of leishmaniasis. Expert Opin Pharmacother. 2019; 20(10): 1251-65. PubMed Abstract | Publisher Full Text

9. Gonçalves SVCB, Costa CHN: Treatment of cutaneous leishmaniasis with 
thermotherapy in Brazil: an efficacy and safety study. An Bras Dermatol. 2018; 93(3): 347-55.

PubMed Abstract | Publisher Full Text | Free Full Text

Faculty Opinions Recommendation

10. Cardona-Arias JA, López-Carvajal L, Tamayo-Plata MP, et al:: Comprehensive economic evaluation of thermotherapy for the treatment of cutaneous leishmaniasis in Colombia. BMC Public Health. 2018; 18(1): 185 PubMed Abstract | Publisher Full Text | Free Full Text | Faculty Opinions Recommendation

11. Velasco-Castrejon O, Walton BC, Rivas-Sanchez B, et al.: Treatment of cutaneous leishmaniasis with localized current field (radio frequency) in Tabasco, Mexico. Am J Trop Med Hyg. 1997; 57(3): 309-12.

PubMed Abstract | Publisher Full Text

12. Bumb RA, Prasad N, Khandelwal $K$, et al.: Long-term efficacy of single-dose radiofrequency-induced heat therapy vs. intralesional antimonials for cutaneous leishmaniasis in India. Br J Dermatol. 2013; 168(5): 1114-9. PubMed Abstract | Publisher Full Text

13. Cardona-Arias JA, Vélez ID, López-Carvajal L: Efficacy of thermotherapy to treat cutaneous leishmaniasis: a meta-analysis of controlled clinical trials. PLOS One. 2015; 10(5): e0122569.

PubMed Abstract | Publisher Full Text | Free Full Text

14. Panagiotopoulos A, Stavropoulos PG, Hasapi V, et al:: Treatment of cutaneous leishmaniasis with cryosurgery. Int J Dermatol. 2005; 44(9): 749-52. PubMed Abstract | Publisher Full Text

15. Laboudi M, Sahibi H, Elabandouni M, et al:: A review of cutaneous leishmaniasis in Morocco: A vertical analysisto determine appropriate interventions for control and prevention. Acta Trop. 2018; 187: 275-83. PubMed Abstract | Publisher Full Text

16. Shaddel M, Sharifi I, Karvar M, et al.: Cryotherapy of cutaneous leishmaniasis caused by Leishmania major in BALB/c mice: A comparative experimental study. J Vector Borne Dis. 2018; 55(1): 42-6. PubMed Abstract | Publisher Full Text | Faculty Opinions Recommendation

17. López-Carvajal L, Cardona-Arias JA, Zapata-Cardona MI, et al.: Efficacy of cryotherapy for the treatment of cutaneous leishmaniasis: meta-analyses of clinical trials. BMC Infect Dis. 2016; 16: 360 .

PubMed Abstract | Publisher Full Text | Free Full Text

18. Heras-Mosteiro J, Monge-Maillo B, Pinart M, et al.: Interventions for Old World cutaneous leishmaniasis. Cochrane Database Syst Rev. 2017; 12(12): CD005067. PubMed Abstract | Publisher Full Text | Free Full Text

19. Refai WF, Madarasingha NP, Sumanasena B, et al.: Efficacy, Safety and CostEffectiveness of Thermotherapy in the Treatment of Leishmania donovaniInduced Cutaneous Leishmaniasis: A Randomized Controlled Clinical Trial. Am $J$ Trop Med Hyg. 2017; 97(4): 1120-6.

PubMed Abstract | Publisher Full Text | Free Full Text

20. Shamsi Meymandi S, Zandi S, Aghaie $\mathrm{H}$, et al: Efficacy of $\mathrm{CO}_{2}$ laser for treatment of anthroponotic cutaneous leishmaniasis, compared with combination of cryotherapy and intralesional meglumine antimoniate. J Eur Acad Dermatol Venereol. 2011; 25(5): 587-91.

PubMed Abstract | Publisher Full Tex

21. Hilerowicz Y, Koren A, Mashiah J, et al.: Fractional ablative carbon dioxide laser followed by topical sodium stibogluconate application: A treatment option for pediatric cutaneous leishmaniasis. Pediatr Dermatol. 2018; 35(3): 366-9.

PubMed Abstract | Publisher Full Text | Faculty Opinions Recommendation

22. Siadat $\mathrm{AH}$, Zolfaghari $\mathrm{A}$, Shahmoradi Z, et al:: Application of laser for treatment of cutaneous leishmaniasis: a review of literature. Lasers Med Sci. 2020; 35(7) 1451-7.

PubMed Abstract | Publisher Full Text

23. Rakcheev AP, Chistiakova IA, Kamennykh PV: [The successful treatment of cutaneous leishmaniasis with an argon laser]. Vestn Dermatol Venerol. 1989; (12): 53-5.

PubMed Abstract

24. Goyonlo VM, Karrabi M, Kiafar B: Efficacy of erbium glass laser in the treatment of Old World cutaneous leishmaniasis: A case series. Australas $J$ Dermatol. 2019; 60(1): e29-e32.

PubMed Abstract | Publisher Full Text | Faculty Opinions Recommendation

25. Omidian M, Jadbabaei M, Omidian E, et al.: The effect of Nd:YAG laser therapy on cutaneous leishmaniasis compared to intralesional meglumine antimoniate. Postepy Dermatol Alergol. 2019; 36(2): 227-31.

PubMed Abstract | Publisher Full Text | Free Full Text |

Faculty Opinions Recommendation

26. Slaoui W, Chiheb S, Benchikhi H: [Efficacy of pulsed-dye laser on residual red lesions of cutaneous leishmaniasis]. Ann Dermatol Venereol. 2015; 142(1): 17-20.

PubMed Abstract | Publisher Full Text

27. Elsaie ML, Ibrahim SM: The effect of pulsed dye laser on cutaneous leishmaniasis and its impact on the Dermatology Life Quality Index. $J$ Cosmet Laser Ther. 2018; 20(3): 152-5.

PubMed Abstract | Publisher Full Text | Faculty Opinions Recommendation

28. Uzun S, Gürel MS, Durdu M, et al:: Clinical practice guidelines for the diagnosis and treatment of cutaneous leishmaniasis in Turkey. Int J Dermatol. 2018; 57(8): 973-82.

PubMed Abstract | Publisher Full Text

29. Salah AB, Messaoud BN, Guedri E, et al:: Topical paromomycin with or without gentamicin for cutaneous leishmaniasis. N Engl J Med. 2013; 368(6): 524-32.

PubMed Abstract | Publisher Full Text | Faculty Opinions Recommendation

30. El-On J, Halevy S, Grunwald MH, et al.: Topical treatment of Old World cutaneous leishmaniasis caused by Leishmania major: a double-blind control study. J Am Acad Dermatol. 1992; 27(2 Pt 1): 227-31.

PubMed Abstract | Publisher Full Text

31. Sosa N, Pascale JM, Jiménez Al, et al.: Topical paromomycin for New World cutaneous leishmaniasis. PLoS Negl Trop Dis. 2019; 13(5): e0007253.

PubMed Abstract | Publisher Full Text | Free Full Text |

Faculty Opinions Recommendation

32. PAHO. Pan American Health Organization: Leishmaniasis in the Americas: Treatment recommendations. 2013.

Reference Source

33. WHO. World Health Organization: Control of Leishmaniasis: report of the meeting of the WHO Expert committee on the control of leishmaniases. Geneva: World Health Organization Technical Report Series 949. 2010;186. Reference Source

34. Shokri A, Abastabar M, Keighobadi M, et al.: Promising antileishmanial activity of novel imidazole antifungal drug luliconazole against Leishmania major: In vitro and in silico studies. J Glob Antimicrob Resist. 2018; 14: 260-5. major: In vitro and in silico studies. J Glob Antimicrob Resist. 2018; 14: 260-5.
PubMed Abstract | Publisher Full Text | Faculty Opinions Recommendation

35. Galvão EL, Rabello A, Cota GF: Efficacy of azole therapy for tegumentary leishmaniasis: A systematic review and meta-analysis. PLOS One. 2017; 12(10): e0186117.

PubMed Abstract | Publisher Full Text | Free Full Text

36. Michelerio A, Barruscotti S, Bossi G, et al.: Pediatric Old World cutaneous leishmaniasis treated with oral fluconazole: A case series. Pediatr Dermatol. 2018; 35(3): 384-7.

PubMed Abstract | Publisher Full Text | Faculty Opinions Recommendation

37. Kariyawasam R, Challa P, Lau R, et al:: Susceptibility testing of Leishmania spp. against amphotericin $B$ and fluconazole using the Sensititre ${ }^{\mathrm{TM}}$ YeastOne ${ }^{\text {TM }}$ YO9 platform. BMC Infect Dis. 2019; 19(1): 593. PubMed Abstract | Publisher Full Text | Free Full Text | Faculty Opinions Recommendation

38. Abu Ammar A, Nasereddin A, Ereqat S, et al:: Amphotericin B-loaded nanoparticles for local treatment of cutaneous leishmaniasis. Drug Deliv Transl Res. 2019; 9(1): 76-84.

PubMed Abstract | Publisher Full Text | Faculty Opinions Recommendation

39. Mosimann V, Neumayr A, Paris DH, et al.: Liposomal amphotericin B treatment of Old World cutaneous and mucosal leishmaniasis: A literature review. Acta Trop. 2018; 182: 246-50.

PubMed Abstract | Publisher Full Text | Faculty Opinions Recommendation

40. Dorlo TPC, Balasegaram M, Beijnen JH, et al.: Miltefosine: A review of its pharmacology and therapeutic efficacy in the treatment of leishmaniasis. $J$ Antimicrob Chemother. 2012; 67(11): 2576-97.

PubMed Abstract | Publisher Full Text

41. Aronson N, Herwaldt BL, Libman M, et al.: Diagnosis and Treatment of Leishmaniasis: Clinical Practice Guidelines by the Infectious Diseases Society of America (IDSA) and the American Society of Tropical Medicine and Hygiene (ASTMH). Am J Trop Med Hyg. 2017; 96(1): 24-45. PubMed Abstract | Publisher Full Text | Free Full Text

42. Sunyoto $\mathrm{T}$, Potet $\mathrm{J}$, Boelaert $\mathrm{M}$ : Why miltefosine-a life-saving drug for leishmaniasis-is unavailable to people who need it the most. BMJ Glob Health. 2018; 3(3): e000709.

PubMed Abstract | Publisher Full Text | Free Full Text

43. Christen JR, Bourreau E, Demar M, et al:: Use of the intramuscular route to administer pentamidine isethionate in Leishmania guyanensis cutaneous leishmaniasis increases the risk of treatment failure. Travel Med Infect Dis. 2018; 24: 31-6.

PubMed Abstract | Publisher Full Text | Faculty Opinions Recommendation

44. Lima ML, Abengózar MA, Nácher-Vázquez M, et al:: Molecular Basis of the Leishmanicidal Activity of the Antidepressant Sertraline as a Drug Repurposing Candidate. Antimicrob Agents Chemother. 2018; 62(12): e01928-18. PubMed Abstract | Publisher Full Text | Free Full Text | Faculty Opinions Recommendation

45. Romanelli MM, da Costa-Silva TA, Cunha-Junior E, et al: Sertraline Delivered in Phosphatidylserine Liposomes Is Effective in an Experimental Model of Visceral Leishmaniasis. Front Cell Infect Microbiol. 2019; 9: 353 PubMed Abstract | Publisher Full Text | Free Full Text | Faculty Opinions Recommendation

46. da Silva Rodrigues JH, Miranda N, Volpato H, et al.: The antidepressant clomipramine induces programmed cell death in Leishmania amazonensis 
through a mitochondrial pathway. Parasitol Res. 2019; 118(3): 977-89. PubMed Abstract | Publisher Full Text | Faculty Opinions Recommendation

47. de Macedo-Silva ST, de Oliveira Silva TLA, Urbina JA, et al:: Antiproliferative, Ultrastructural, and Physiological Effects of Amiodarone on Promastigote and Amastigote Forms of Leishmania amazonensis. Mol Biol Int. 2011; 2011: 876021. PubMed Abstract | Publisher Full Text | Free Full Text

48. Pinto EG, Tempone AG: Activity of the antiarrhythmic drug amiodarone against Leishmania (L.) infantum: An in vitro and in vivo approach. J Venom Anim Toxins Incl Trop Dis. 2018; 24: 29. PubMed Abstract | Publisher Full Text | Free Full Text | Faculty Opinions Recommendation

49. Bemani E, Oryan A, Bahrami S: Effectiveness of amiodarone in treatment of cutaneous leishmaniasis caused by Leishmania major. Exp Parasitol. 2019; 205: 107747.

PubMed Abstract | Publisher Full Text | Faculty Opinions Recommendation

50. Oryan A, Bemani E, Bahrami S: Emerging role of amiodarone and dronedarone, as antiarrhythmic drugs, in treatment of leishmaniasis. Acta Trop. 2018; 185 34-41. PubMed Abstract | Publisher Full Text

51. 2 Zheng ZW, Li J, Chen $\mathrm{H}$, et al: Evaluation of in vitro antileishmanial efficacy of cyclosporin $A$ and its non-immunosuppressive derivative, dihydrocyclosporin A. Parasit Vectors. 2020; 13(1): 94 PubMed Abstract | Publisher Full Text | Free Full Text Faculty Opinions Recommendation

52. El Hajj R, Youness BH, Lachaud L, et al.: EAPB0503: An Imiquimod analog with potent in vitro activity against cutaneous leishmaniasis caused by Leishmania major and Leishmania tropica. PLoS Negl Trop Dis. 2018; 12(11): e0006854.

PubMed Abstract | Publisher Full Text | Free Full Text Faculty Opinions Recommendation

53. Miranda-Verastegui C, Tulliano G, Gyorkos TW, et al:: First-line therapy for human cutaneous leishmaniasis in Peru using the TLR7 agonist imiquimod in combination with pentavalent antimony. PLoS Negl Trop Dis. 2009; 3(7): e491. PubMed Abstract | Publisher Full Text | Free Full Text

54. Miranda-Verástegui C, Llanos-Cuentas A, Arévalo I, et al:: Randomized, doubleblind clinical trial of topical imiquimod $5 \%$ with parenteral meglumine antimoniate in the treatment of cutaneous leishmaniasis in Peru. Clin Infect Dis. 2005; 40(10): 1395-403.

PubMed Abstract | Publisher Full Text

55. Arevalo I, Tulliano G, Quispe A, et al:: Role of imiquimod and parentera meglumine antimoniate in the initial treatment of cutaneous leishmaniasis. Clin Infect Dis. 2007; 44(12): 1549-54. PubMed Abstract | Publisher Full Text

56. Mehravaran A, Nasab MR, Mirahmadi H, et al:: Protection induced by Leishmania Major antigens and the imiquimod adjuvant encapsulated on liposomes in experimental cutaneous leishmaniasis. Infect Genet Evol. 2019; 70: $27-35$

PubMed Abstract | Publisher Full Text | Faculty Opinions Recommendation

57.

Tajuddeen N, Isah MB, Suleiman MA, et al:: The chemotherapeutic potentia of chalcones against leishmaniases: A review. Int J Antimicrob Agents. 2018;
51(3): 311-8.

PubMed Abstract | Publisher Full Text | Faculty Opinions Recommendation

58. Rocha VPC, Quintino da Rocha C, Ferreira Queiroz E, et al.: Antileishmanial Activity of Dimeric Flavonoids Isolated from Arrabidaea brachypoda. Molecules. 2018; 24(1): 1

PubMed Abstract | Publisher Full Text | Free Full Text | Faculty Opinions Recommendation

59. Fernandes NdS, Desoti VC, Dias A, et al.: Styrylpyrone, isolated from an Amazon plant, induces cell cycle arrest and autophagy in Leishmania amazonensis. Nat Prod Res. 2020: 1-5

PubMed Abstract | Publisher Full Text | Faculty Opinions Recommendation

60. Macêdo CG, Fonseca MYN, Caldeira AD, et al.: Leishmanicidal activity of Piper marginatum Jacq. from Santarém-PA against Leishmania amazonensis. Exp Parasitol. 2020; 210: 107847.

PubMed Abstract | Publisher Full Text | Faculty Opinions Recommendation

61. Tasdemir D, Kaiser M, Demirci B, et al:: Antiprotozoal Activity of Turkish Origanum onites Essential Oil and Its Components. Molecules. 2019; 24(23): 4421.

PubMed Abstract | Publisher Full Text | Free Full Text |

Faculty Opinions Recommendation

62. Badirzadeh A, Heidari-Kharaji M, Fallah-Omrani V, et al:: Antileishmanial activity of Urtica dioica extract against zoonotic cutaneous leishmaniasis. PLoS Negl Trop Dis. 2020; 14(1): e0007843.

PubMed Abstract | Publisher Full Text | Free Full Text | Faculty Opinions Recommendation

63. Barros GAC, Pereira AV, Barros LC, et al:: In vitro activity of phospholipase $\mathbf{A}_{2}$ and of peptides from Crotalus durissus terrificus venom against amastigote and promastigote forms of Leishmania (L.) infantum chagasi. J Venom Anim Toxins Incl Trop Dis. 2015; 21: 48 PubMed Abstract | Publisher Full Text | Free Full Text

64. Macedo SRA, de Barros NB, Ferreira AS, et al:: Biodegradable microparticles containing crotamine isolated from Crotalus durissus terrificus display antileishmanial activity in vitro. Pharmacology. 2015; 95(1-2): 78-86. PubMed Abstract | Publisher Full Text

65. Coutinho De Oliveira B, Duthie MS, Alves Pereira VR: Vaccines for leishmaniasis and the implications of their development for American tegumentary leishmaniasis. Hum Vaccin Immunother. 2020; 16(4): 919-30. PubMed Abstract | Publisher Full Text | Free Full Text

66. Iborra S, Solana JC, Requena JM, et al:: Vaccine candidates against leishmania under current research. Expert Rev Vaccines. 2018; 17(4): 323-34. PubMed Abstract | Publisher Full Text | Faculty Opinions Recommendation

67. Moafi M, Rezvan H, Sherkat R, et al.: Leishmania Vaccines Entered in Clinical Trials: A Review of Literature. Int J Prev Med. 2019; 10: 95. PubMed Abstract | Publisher Full Text | Free Full Text | Faculty Opinions Recommendation

68. Osman M, Mistry A, Keding A, et al.: A third generation vaccine for human visceral leishmaniasis and post kala azar dermal leishmaniasis: First-inhuman trial of ChAd63-KH. PLoS Negl Trop Dis. 2017; 11(5): e0005527. PubMed Abstract | Publisher Full Text | Free Full Text 